\title{
The Identity of Subject in Aeschylus, Cho. 32-36
}

\author{
Nina A. Almazova \\ St. Petersburg State University, \\ 7-9, Universitetskaya nab., St. Petersburg, 199034, Russian Federation; n.almazova@spbu.ru
}

For citation: Nina A. Almazova. The Identity of Subject in Aeschylus, Cho. 32-36. Philologia Classica 2018, 13(1), 181-188. https://doi.org/10.21638/11701/spbu20.2018.114

In the parodos of the Choephori by Aeschylus the chorus sings of a nightmare that made Clytemnestra send libations to the grave of Agamemnon in a vain attempt to pacify his wrath and

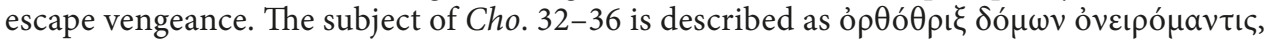

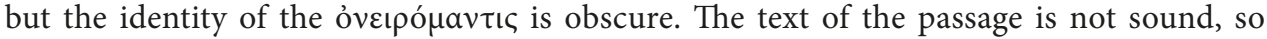
various emendations have been attempted which presuppose different interpretations of its subject. The proposal of F. Blass to delete Фоĩ $\beta$ o in v. 32 seems the most convincing. This word was probably an interpolation aimed at inserting an explicitly named subject into the text. However, Фоĩßoৎ is most implausible as a subject, since Apollo has nothing to do with grim underworld divinities as well as with sending prophetic dreams. Fear would be seman-

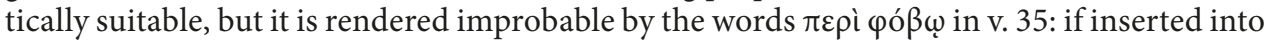
the text, the noun $\varphi$ ó $\beta$ oৎ would become both a subject and a secondary element of the same

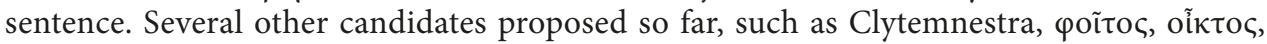
are also implausible. The dream of Clytemnestra as a subject suits the context perfectly, but it could be hardly called "an interpreter of dreams". Yet Aeschylus is fond of rethinking the sense of compounds according to their etymological potential. The paper argues that òveıó $\mu a v \tau ı$ c is used in the meaning 'Dream the prophet', i.e. 'prophetic dream'.

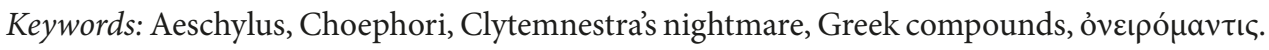

(C) St. Petersburg State University, 2018 


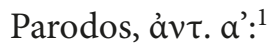

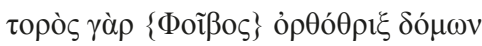

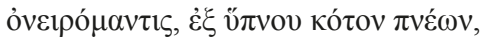

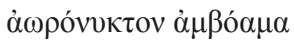

35 $\mu v \chi o ́ \theta \varepsilon v$ हैं $\alpha \kappa \varepsilon \pi \varepsilon \rho i ̀ ~ \varphi o ́ \beta \omega$,

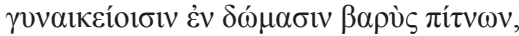
$\kappa \rho \imath \tau \alpha \grave{i}<\delta \dot{\varepsilon}>\tau \tilde{\omega} v \delta^{\prime}$ ỏveıı́́ $\tau \omega v$

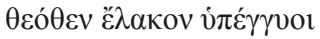

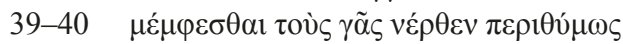

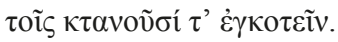

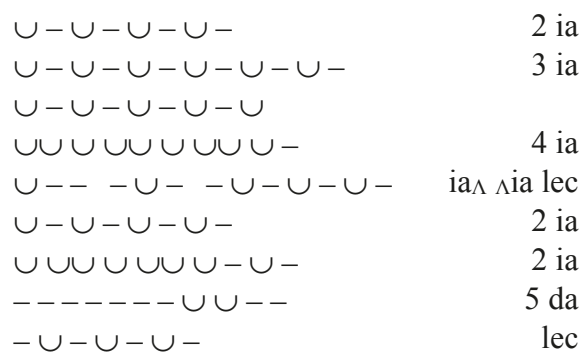

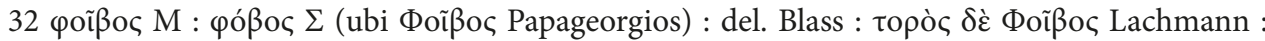

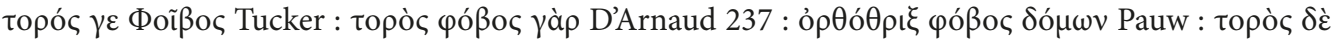

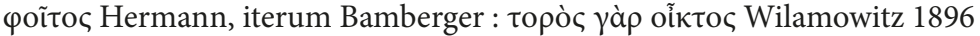

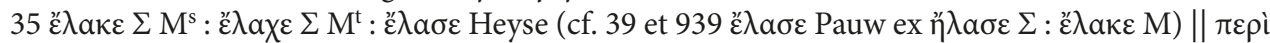

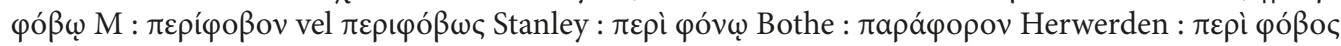
Bowen

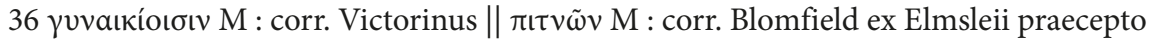

$37<\delta \dot{\varepsilon}>$ Portus : $<\tau \varepsilon>$ Porson

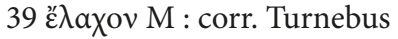

The chorus sings of a nightmare that made Clytemnestra send libations to the grave of Agamemnon in a vain attempt to pacify his wrath and escape vengeance. Later on (514550) the audience, together with Orestes, will learn the details: the queen dreamed that she gave birth to a snake which suckled blood along with the milk from her breast.

Now, what person or power is the subject of $32-36$ ?

The transmitted text is not sound: the antistrophe is two syllables longer than the strophe. It is possible to add the tenth, catalectic, iambus to the nine present in the stro-

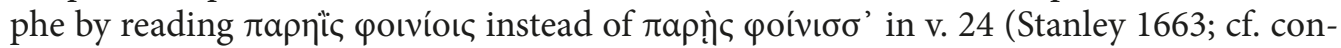
tra Blass 1898, 181-182; 1906, 80). However, emendation of the antistrophe looks more promising, since it contains an obvious weak point: the word Фоĩßoৎ — exactly two syllables long - does not fit the iambic metrical context (we need a vowel after $\gamma a$ á $\rho$ to scan

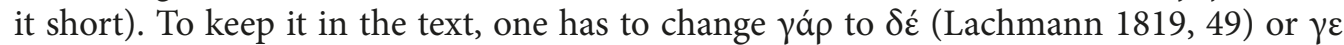
(Tucker 1901, 16-17), but it is hardly worth the effort, since the sense is also questionable. Moreover, a rationale for the corruption is obvious, in that Фоĩßoৎ could be an interpolated gloss (Murray 1937, 278) aimed at answering the same question that we are dealing

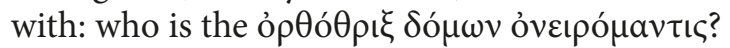

However, this guess of the glossator is most implausible. It is the chthonic powers, first of all the dead Agamemnon himself, who are wrathful and must be appeased (cf. 39-41). To these very powers Electra and Orestes pray for help in a long scene at the king's tomb. Meanwhile Apollo, though he commanded Orestes to avenge the death of his father in a prophecy (a fact first mentioned later, in 269-297²), has nothing in common with grim

${ }^{1}$ Edition cited: West 1998, with an extended apparatus criticus.

2 It is possible that the missing lines of the Prologue spoken by Orestes contained some reference to the command of Apollo (Winnington-Ingram 1933, 98), but Garvie $(1970,82)$ considers the possibility that the Prologue was not a long one and that we have most of it: "It is at least arguable that Apollo's command was not mentioned at this point, that he comes in only later when Orestes describes his oracle". 
underworld divinities: see e.g. Stesich. fr. 271 Finglass and Eur. Suppl. 974b-976 (Plut. De E apud Delphos 394 b cites them to make this very point). The same contrast between Apollo and the realm of death is expressed in Aesch. Ag. 1074-1075, 1078-1079 and Sept. $854-860 .^{3}$

It is true that Clytemnestra's attempt to appease the spirit of her husband turns out to be a mistake: it results in the meeting of Electra and Orestes and thus brings the retribution nearer instead of averting it. However, it is hardly possible to claim, with Verrall 1893, 6, that the prophets of the palace have mistaken Apollo for the chthonic powers in interpreting the dream. To leave such a mistake without an explicit comment would be

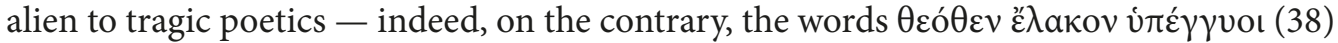
underline the truth of interpretation. Besides we can support the seers of Argos: the snake that appears in Clytemnestra's dream has obvious chthonic associations, and the Earth is regularly the source of dreams, ${ }^{4}$ whereas Apollo does not use them for warning. ${ }^{5}$

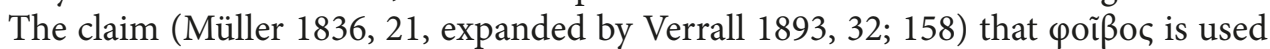
not for Apollo, but generically for 'prophetic possession', is unfounded (such a meaning is not attested, while the etymological significance 'bright' must have been always perceivable) as well as implausible (the context implies personification, and what other person but Apollo could Фoĩßoৎ mean?).

For all these reasons, Phoebus (even assuming that he was only implied and not named in the text) seems the least suitable candidate.

Neither is Clytemnestra a possible variant: it must have been she who screamed

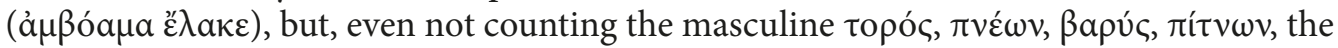
queen could hardly be said to 'breath anger' or to 'fall gravely upon the women's chambers' (unless we imagine that Clytemnestra unleashed her fury upon her female slaves as she woke up).

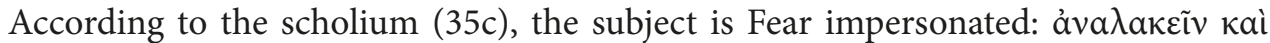

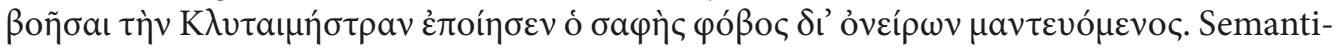

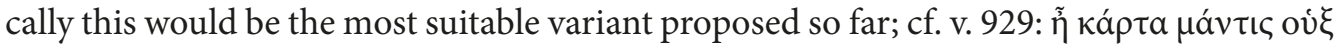

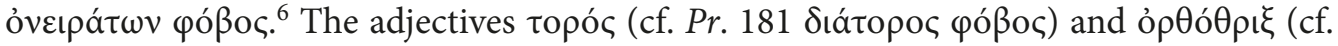
hair rising with terror e.g. in Aesch. Sept. 564; Soph. OC 1624-1625) suit it perfectly. It is possible that the scholiast has not just summarised the passage in a free paraphrase, but read the word $\varphi$ óßoৎ in his text (cf. the scholium 35b cited in n. 8) - in this case $\varphi$ ó

${ }^{3}$ Cf. Garvie 1986, 57: "Apollo has nothing to do with the interpretation of dreams in the palace of Argos, or with the uttering of cries through Clytemnestra's mouth"; Rutherford 2001, 49: "Apollo had no part in the chthonic sphere". Rose 1958, 123-124 finds the assumption that óveıóp the context meant Apollo so ridiculous that he refuses to believe someone could have ever proposed Фоĩ $\beta$ ○ as a gloss.

4 Cf. Eur. Hec. 70-71; IT 1263-1267; Aristoph. Ran. 1331-1332; see Kenner 1939, 450-451: "ein Heer von Träumen $\langle\ldots\rangle$, das irgendwo ganz im Westen oder unter der Erde, immer in der Nahe des Totenreichs liegt. Aus dem schattenhaften, geisterähnlichen Charakter der öveıpot erklärt es sich auch, wenn $<\ldots .>$ dunkle, chthonische Gottheiten ihnen das Leben gegeben haben: die Nacht $\langle\ldots\rangle$ oder die Erde $\langle\ldots\rangle$ oder Erebos und Nacht"; Garvie 1970, 84: "Earth is the mother of all dreams, but this is a particularly appropriate one for her to send because it reveals her own anger to the living"; Garvie 1986, 59.

${ }^{5}$ Cf. Klausen 1835, 5: "nullo modo vocem $\varphi$ oĩßo fert sensus. Neque enim ullus hic locus est adiectivo

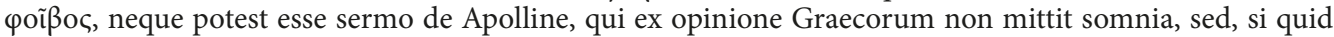
ei in his rebus agendum, interpretatur. De interpretatione autem in his versibus minime dicitur, sed postea demum".

6 The ms. gives this line to Orestes, but it may be plausibly assigned to Clytemnestra, see Garvie 1986, 301-302. 
was either a genuine reading or an intrusive gloss (Bowen 1986, 36), whereas the transmitted Фoĩßo c could be a mechanical scribal mistake, an emendation provoked by accumulation of prophetic vocabulary (Headlam-Thomson 1938, 164), or else an unskillful attempt at improving the metre (Klausen 1835, 5; Blass 1898, 180; 1906, 81). A series of interven-

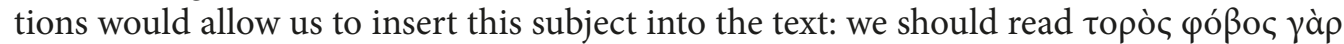

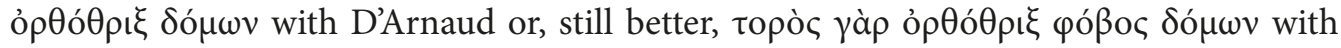
Pauw in v. 32, ${ }^{7}$ and accordingly add two syllables to the strophe, as indicated above.

Yet the subject $\varphi$ ó $\beta$ oc is rendered improbable by the words $\pi \varepsilon \rho i$ i ó $\beta \omega$ in v. 35: the same noun acts as a subject and a secondary element of the sentence. ${ }^{8}$ Attempting to avoid

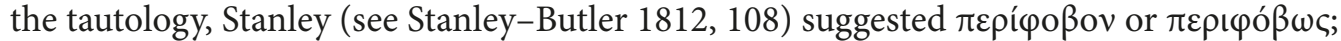

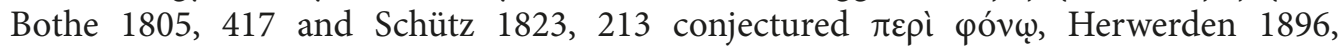
$39 \pi \alpha \rho a ́ \varphi \rho \rho o v$, but on its own account the expression $\pi \varepsilon \rho \grave{~} \varphi$ ó $\beta \omega$ is not suspicious (pace

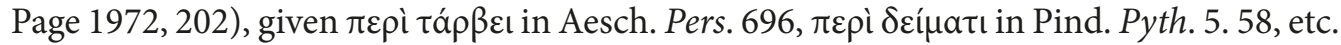
(Groeneboom 1949, 108 n. 8). Attempts have been made (Conington 1857, 8; Paley 1879, 490; Headlam-Thomson 1938, 165; Rose 1958, 124) to legitimise such a slip by adducing

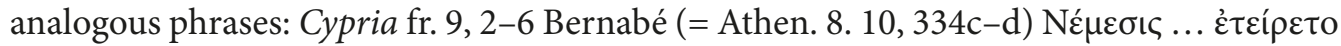

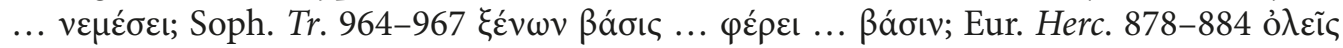

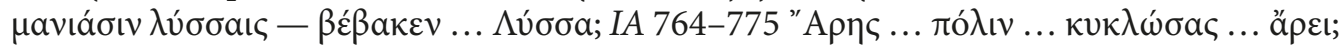

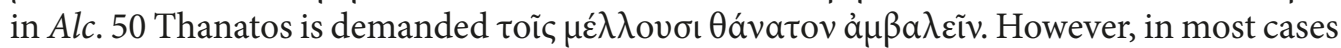
the tautology may be plausibly avoided by means of textual criticism, ${ }^{9}$ and the rest are not equally grave. ${ }^{10}$ It proves a much more economic solution to do without póßos in Cho. 32.

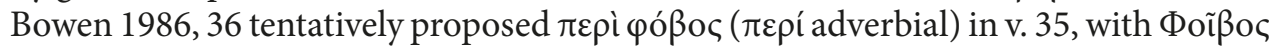
removed in v. 32. In this case, $\pi \varepsilon \rho$ í was wrongly taken as a preposition and provoked corruption of $\varphi$ ó $\beta$ os to $\varphi$ ó $\beta \omega$. Hence the need to identify the subject; someone who saw that fear was an effective variant made a marginal note $\varphi$ óßoc, which later found its way to v. 32. However, the position of $\varphi$ óßoৎ so far away from topóc is suspicious, and adverbial $\pi \varepsilon \rho$ í is not attested in Aeschylus. ${ }^{11}$

Hermann 1839, $52=1852,31$ and, independently, Bamberger 1840, 8 proposed topò $\varsigma$

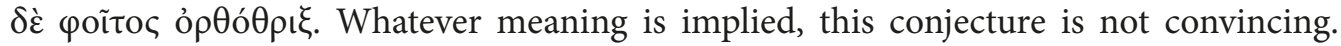
Bamberger intended $\varphi$ ĩ̃oৎ to mean 'madness', but it can hardly have this significance without $\varphi \rho \varepsilon v \tilde{\omega} v$ (as in Aesch. Sept. 661), and Madness is an unsuitable source of a clear and true prophetic message. Paley 1879, 490 implausibly interpreted $\varphi$ oĩ

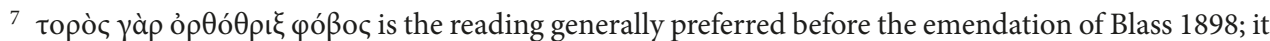
is accepted e.g. by Blomfield 1834; Conington 1857; Weil $1860=1903$; Dindorf 1880; Kirchhoff 1880; Sidgwick 1915; Headlam-Thomson 1938.

8 The tautology is considered intolerable by Hermann 1839, 51; Schütz 1823, 213; Bothe 1831, 150; Bamberger 1840, 8; Wilamowitz 1896, 158; Blass 1906, 81. The same opinion is suggested by the scholiast's

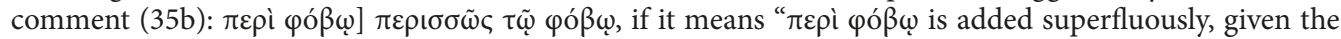
subject $\varphi$ óßoৎ above” (de Jongh 1856, 79; cf. Paley 1879, 490; contra Verrall 1893, 158).

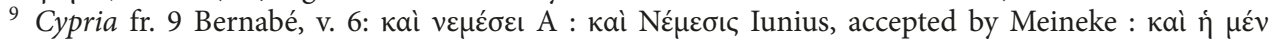

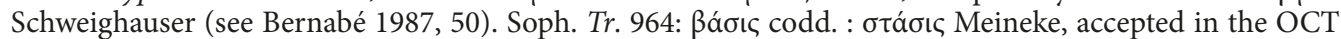
edition (see Lloyd-Jones-Wilson 1990). In $I A$ the text of the whole epode is unsound; 775: ä $\rho \varepsilon ı$ ( $\varepsilon \mathrm{l}$ ex $\omega$

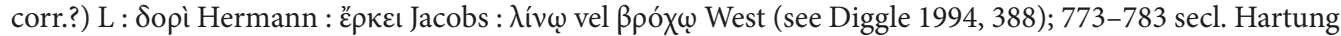
(see Stockert 1992, II, 424-425).

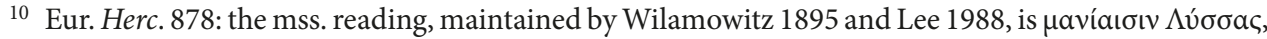
and anyway this passage is not a parallel, since $\Lambda$ $\sigma \sigma \alpha$ does not appear as both the subject and the object

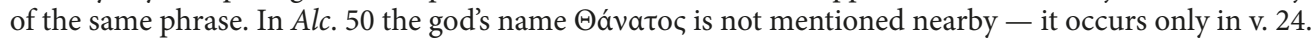

11 The only case mentioned in Italie 1964, 243 s.v. (Sept. 345) is the result of a conjecture. 
nightly visitant' in the form of a dream", although the word is otherwise attested only in the meaning 'a repeated going or coming' (cf. LSJ s.v.) and not as a nomen agentis. Фoĩ os would have suited the story of Lady Macbeth rather than Clytemnestra.

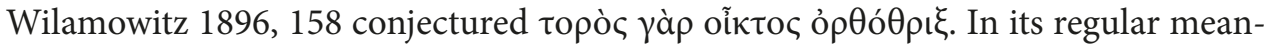
ing 'pity, compassion' (Aesch. Suppl. 486 ms., Pr. 239) or 'lamentation, piteous wailing' (Aesch. Sept. 51; Cho. 411; Suppl. 59; 386), oĩktoৎ is an emotion out of place in this scene, where the anger of the dead and the fear of the murderer reign: even after Clytemnestra wakes she does not lament - she acts, and her household is far from compassionate. Wilamowitz claimed that Aeschylus used oĩktoc in the etymological meaning 'outcry' (at-

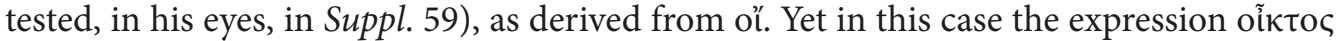

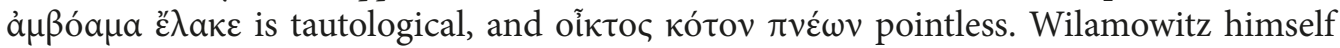
rejected this proposal in his edition of 1914.

None of these conjectures is accepted in the twentieth-century editions of the Choephori, which for the most part follow F. Blass in deleting Фоĩ $\beta$ os. ${ }^{12}$ Blass at first suggested that the subject implied was the dream of Clytemnestra. ${ }^{13}$ However, this version was later abandoned by its author and found no supporters - presumably on the ground that an "interpreter of dreams" could not itself be a dream. Blass argued later $(1906,81)$ that the power acting in this passage was the evil daemon of the house mentioned so often in the Oresteia. This is not impossible, but it should be noted that the daemon is not named here, unlike in other cases. ${ }^{14}$

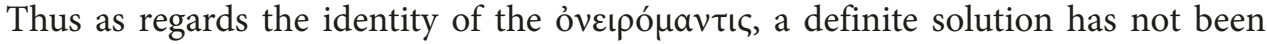
found, ${ }^{15}$ but the search for it has clearly indicated the problem: modern editors as well as ancient glossators proceed in their attempts from the feeling that the phrase is not clear without a subject indicated explicitly in the text. ${ }^{16}$

I believe that the subject is in fact named rather than hinted at in the text: it is the 'prophetic dream', óveı

The word-building model of two nouns (in the nominative), one of which determines the other, is represented in Greek. Such compounds are called determinative appositive,

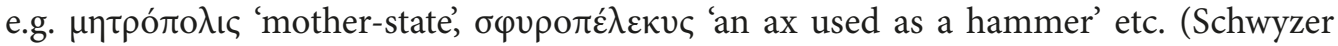
$1953,453)$. If both parts are used on equal terms, such cases are classified as copulative compounds (Kühner-Blass 1892, 318).

12 E.g. Wilamowitz 1914, Murray 1937, Untersteiner 1947, Groeneboom 1949, Page 1972, Garvie 1986, Mazon 1993, West 1998.

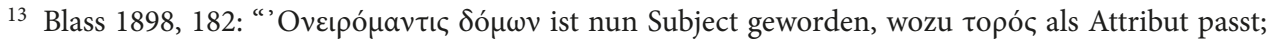
der ỏveıpó $\mu a v \tau \iota c$ ist aber nichts als der personificirte weissagende Traum”.

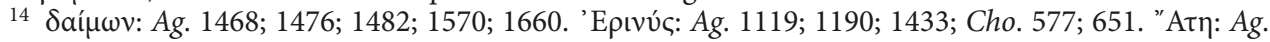

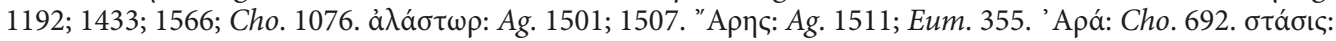
Ag. 1117. póvoc: Cho. 806.

15 The comment of Tucker 1901, 17 looks like an attempt to accept all the explanations at once evoked by desperation: "The poet doubtless meant the figurative Фoĩ

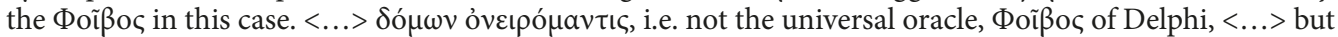
a prophetic possession sent by a tutelary genius of the house and taking the shape of a dream". As Mazon 1993, 81 n. 1 claimed that the "prophet" was Clytemnestra's remorse (the same in Casevits 1982, 70), he only provided an interpretation of Aeschylus' image in terms of modern psychology, rather than revealed its structure.

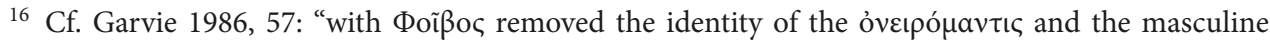
participles are obscure". 


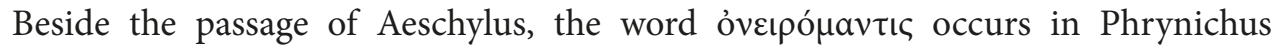
(Praeparatio sophistica p. 91, 1. 7-8 De Borries) and in a magical papyrus of the third century AD (Preisendanz, PMG VII 795); the fragment of "The Lydians" by Magnes adduced

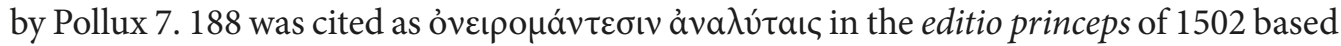

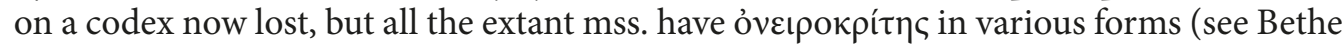
1931,103 ). Each time, it seems, the meaning is 'interpreter of dreams' (insofar as the context - or the lack of it - allows a safe understanding). Yet - $\mu a v \tau$ เ

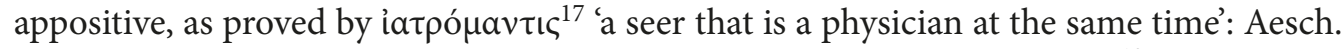

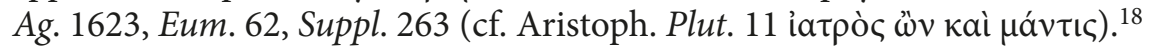

It has been noted long ago that Aeschylus is fond of rethinking the sense of words according to their etymological potential (see especially Schuursma 1932). Among examples of changing the usual meaning of compounds are: $\theta \varepsilon \circ \beta \lambda \alpha \beta \varepsilon \tau$ 'do harm to the gods' instead of 'be damaged by the gods' (Pers. 831); паүкрати́ 'overcoming in every respect' instead of 'overcoming everyone' (Ag. 1648); đá $\mu \mu \alpha \chi 0 \varsigma$ 'fighting with everyone'

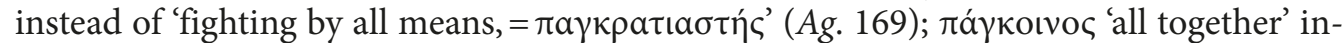

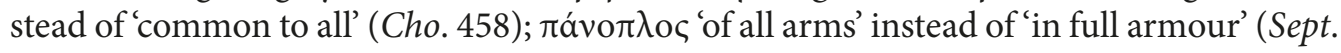

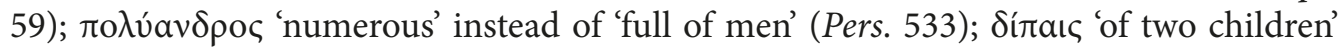
instead of 'having two children' (Cho. 334); ${ }^{19}$ ka $\lambda \lambda i$ ía cs 'beautiful child' instead of 'having beautiful children' (Ag. 762) ${ }^{20}$ An interesting case is the hapax $\theta \eta \lambda$ vктóvo, which means 'female killer', though one would aspect 'killer of women' (Pr. 861). ${ }^{21}$

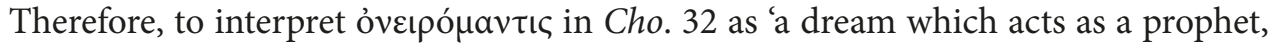
i.e. has prophetic significance' seems in accordance both with Greek semantics and Aeschylus' poetical technique. As a subject the Dream is perfectly compatible with all the participles and the verb. ${ }^{22}$ Moreover, its impersonation as a prophet may be confirmed by

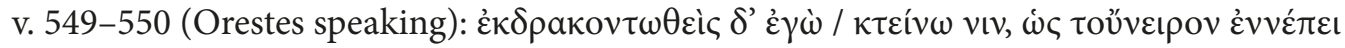
Tó $\delta \varepsilon^{23}$

\section{References}

D'Arnaud (Arnaldus), G. Specimen animadversionum criticarum ad aliquos scriptores Graecos. Harlingae, 1728 (Amstelaedami, 1730).

Bamberger F. (ed.). Aeschyli Choephori. Gottingae, Vanderhoeck et Ruprecht, 1840.

Bernabé A. (ed.). Poetarum epicorum Graecorum testimonia et fragmenta. Pars I. Leipzig, Teubner, 1987.

Bethe E. (ed.). Pollucis Onomasticon. Vol. II: Libri VI-X. Stuttgart; Leipzig, Teubner, 1931.

Blass F. W.Zu Aischylos Choephoren. Hermes. 1898, 33, 179-182.

Blass F. W. (ed., comm.). Aeschylos' Choephoren. Halle a. d. S., Niemeyer, 1906.

17 iatpó $\mu a v \tau \iota c$ is classified as appositive in Schwyzer 1953, 453 and as copulative in Kühner-Blass $1892,318$.

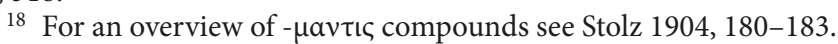

19 Schuursma 1932, 121-126.

${ }^{20}$ Fraenkel 1950, II, 348-349.

${ }^{21}$ Schuursma 1932, 126-127.

22 The Dream seems so evident a possibility that it occurred almost unconsciously to some scholars who read $\varphi$ óßoৎ or Фoĩßoৎ, as reflected in their comments, e.g. Paley 1879, 490: "Klausen [1835] objects

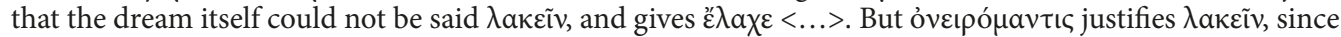
the dream thereby assumes the character of a person". Weir Smith 1926, 162: "Phoebus' is used for a prophetic 'possession', which assails Clytaemestra as a nightmare $\langle\ldots\rangle$ so that her vision is itself called an

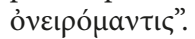

${ }^{23}$ I sincerely appreciate the language assistance of P. J. Finglass. 
Blomfield C. J. (ed., comm.). Aeschyli Choephoroe. Londini, Taylor, $1834^{3}$.

De Borries I. (ed.). Phrynichi Praeparatio sophistica. Lipsiae, Teubner, 1911.

Bothe F. H. (ed., comm.). Aeschyli dramata quae supersunt. Lipsiae, Weidmann, 1805.

Bothe F. H. (ed.). Poetae Scaenici Graecorum. Vol. X. Lipsiae, Hahn, 1831.

Bowen A. (ed.). Aeschylus. Choephori. Bristol, Bristol Classical Press, 1986.

Casevits M. Les mots du rêve en grec ancient. Ktéma 1982, 7, 67-73.

Conington J. Aeschylus. The Choephoroe. London, Parker and Son, 1857.

Diggle E. (ed.). Euripidis Fabulae. Vol. III. Oxonii, Clarendon Press, 1994.

Dindorf G. (ed.). Aeschyli tragoediae. Lipsiae, Teubner, $1880^{6}$.

Finglass P. J.; Davies, M. (ed., comm.). Stesichorus. The Poems. Cambridge, University Press, 2014.

Fraenkel E. (ed., comm.). Aeschylus. Agamemnon. Vol. I-III. Oxford, 1950.

Garvie A. F. The Opening of the Choephori. BICS 1970, 17, 79-91.

Garvie A. F. (ed., comm.). Aeschylus. Choephori. Oxford, 1986.

Groeneboom P. (ed., comm.). Aeschylus' Choephoroi. Groningen, Batavia, Wolters, 1949.

Headlam A., Thomson, G. (ed., comm.). The Oresteia of Aeschylus. Vol. I-II. Cambridge, University Press, 1938.

Hermann G. Recension einer Antikritik und zweyer Recensionen von Herrn K. O. Müller, in: Godofredi Hermanni Opuscula. Vol. VII. Lipsiae, Fleischer, 1839, 25-64.

Hermann G. (ed.). Aeschyli Tragoediae. Vol. II. Lipsiae, Weidmann, 1852.

Herwerden H.van. In Aeschylum observationes veteres atque novae. Mnem. 1896, 24, 31-54.

Heyse T. Die Orestie des Aeschylus. Halle, 1884.

Italie G. Index Aeschyleus. Curavit S. L. Radt. Leiden, Brill, $1964^{2}$.

Jongh A. de. Aeschyli Choephorae, cum interpretatione Latina et annotatione. Trajecti ad Rhenum, Kemink et filius, 1856.

Kenner H. Oneiros, RE 1939, 18, 448-459.

Kirchhoff A.(ed.). Aeschyli tragoediae. Berolini, Weidmann, 1880.

Klausen R.H. (ed.). Aeschyli quae supersunt. Vol. I, sect. II: Choephorae. Gothae et Erfordiae, Hennings, 1835.

Kühner R. Ausführliche Grammatik der griechischen Sprache, Tl. 1. Elementar- und Formenlehre. Bd. 2, in neuer Bearb. besorgt von F. Blass. Hannover, Hahn, $1892^{3}$.

Lachmann C. De choricis systematis tragicorum Graecorum libri quattuor. Berolini, Reimer, 1819.

Lee K.H. (ed.). Euripides. Hercules. Leipzig, Teubner, 1988.

Lloyd-Jones H., Wilson N. G. (eds.). Sophoclis Fabulae. Oxonii, Clarendon Press, 1990.

Mazon P. (ed., tr.). Eschyle. Vol.II. Agamemnon - Les choéphores - Les Euménides. Paris, Belles Lettres, 1993.

Müller K. O. Rec. Choephorae, ed. R. Klausen, Gothae 1835. Zeitschrift für die Alterthumswissenschaft. 1836, $1-5,14-44$.

Murray G. (ed.). Aeschyli septem quae supersunt tragoediae. Oxonii, Clarendon Press, $1937^{2}$.

Page D. (ed.). Aeschyli septem quae supersunt tragoediae. Oxford, University Press, 1972.

Paley A. (ed., comm.). The Tragedies of Aeschylus. London, Whittaker and Co., 1879.

Pauw J. C. de (ed.). Aeschyli Tragoediae superstites. Hagae Comitum, 1745.

Porson R. (ed.). Aeschyli tragoediae septem cum versione Latina. Vol. II. London, Payne, 1806.

Portus F. Commentaria in Aeschyli tragoedias (inedita). Lugd. Bat. Bibl. Univ. B. P. L. 180 (post 1568).

Rose H. J. A Commentary on the Surviving Plays of Aeschylus. Amsterdam, N. V. Noord-Hollandische Uitgevers Maatschappij, 1958.

Rutherford I. Pindar's Paean. A reading of the fragments with a survey of the genre. Oxford, University Press, 2001.

Schütz Chr. G. (ed., comm.). Aeschyli tragoediae quae supersunt. Londini, Whittaker, 1823.

Schuursma I. A. De poetica vocabulorum abusione apud Aeschylum. Amstelodami, Paris, 1932.

Schwyzer E. Griechische Grammatik. Bd. 1. Allgemeiner Tell. Lautlehre. Wortbildung. Flexion. München, Beck, $1953^{6}$.

Sidgwick A. Aeschyli tragoediae. Oxford, Clarendon Press, 1915.

Stanley Th. Aeschyli quae extant. London, Flesher, 1663.

Stanley Th., Butler, S. (eds.). Aeschyli tragoediae quae supersunt. T. V. Cantabrigiae, typis ac sumptibus Academicis, 1812.

Stockert W. (ed.). Euripides. Iphigenie in Aulis. Vol. I-II. Vienna, Die Österreichische Akademie der Wissenschaften, 1992. 
Stolz W. Beiträge zur griechischen Wortzusammensetzung und Wortbildung, WSt 1904, 26, 169-184.

Tucker T. G. The Choephori of Aeschylus. With Critical Notes, Commentary, Translation and a Recension of the Scholia. Cambridge, University Press, 1901.

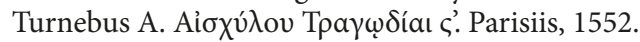

Untersteiner M. (ed., tr.). Eschilo. Le Coefore. Vol. I. Como - Milano, Marzorati, 1947

Verrall A. W. (ed., comm., tr.). The 'Choephori' of Aeschylus. London - New York, Macmillan, 1893.

Weil H. (ed.). Aeschyli quae supersunt tragoediae. Vol. I sect. II. Choephori. Gissae, Ricker, 1860.

Weil H. (ed.). Aeschyli tragoediae. Lipsiae, Teubner, 1903.

Weir Smyth, H. (tr.). Aeschylus. Tragoediae. Vol. II: Agamemnon - Libation-Bearers - Eumenides - Fragments. Appendix and addendum by H.Lloyd-Jones. Cambridge, MA; London, Harvard University Press, 1926.

West M.L. (ed.). Aeschyli tragoediae. Stuttgardiae et Lipsiae, Teubner, 1998.

Wilamowitz-Moellendorff U.von (ed., comm.). Euripides. Herakles. Berlin, Weidmann, 1895.

Wilamowitz-Moellendorff U.von (ed., tr.). Aischylos. Orestie. Zweites Stück. Das Opfer am Grabe. Berlin, Weidmann, 1896.

Wilamowitz-Moellendorff U.von (ed.). Aeschyli Tragoediae. Berolini, Weidmann, 1914.

Winnington-Ingram R. P. The Role of Apollo in the Oresteia. ClR 1933, 47, 97-104.

Received: 12.01 .2018

Final version received: 26.03 .2018

\section{Действующее лицо у Эсхила, Cho. 32-36}

\section{Нина Александровна Алмазова}

Санкт-Петербургский государственный университет,

Российская Федерация, 199034, Санкт-Петербург, Университетская наб., 7-9; n.almazova@spbu.ru

В пароде «Хоэфор» Эсхила хор поет о ночном кошмаре, из-за которого Клитемнестра послала возлияния на могилу Агаменмнона в тщетной попытке умилостивить его дух и избежать возмездия. Действующее лицо фразы Cho. 32-36 описано как ỏ $\theta$ ó $\theta \rho ı \xi$

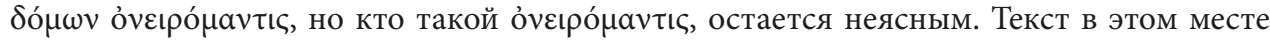
нуждается в эмендации, и предлагались многочисленные варианты его исправления, позволяющие по-разному интерпретировать субъект фразы. Предложение Ф. Бласса атетировать Фоїос в ст. 32 представляется наиболее убедительным. Очевидно, это была интерполяция, цель которой - получить недвусмысленное указание в тексте на действующее лицо. Однако Фоїßоц на эту роль не подходит, поскольку Аполлон не имеет никакого отношения к зловещим хтоническим божествам и не посылает пророческих снов. Подходящим по смыслу было бы подлежащее «страх», однако оно

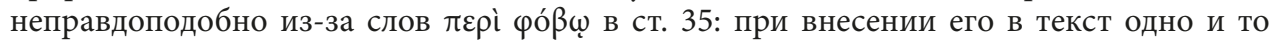
же существительное фо́ßоৎ оказалось бы одновременно главным и второстепенным членом предложения. Другие предлагавшиеся варианты, такие как Клитемнестра,

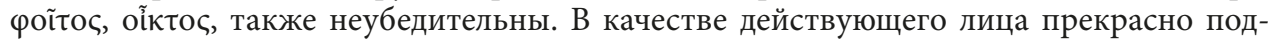
ходит персонифицированный сон Клитемнестры, однако сон едва ли можно назвать «толкователем снов». Между тем известно, что Эсхил склонен переосмысливать композиты, придавая им необычные, но этимологически возможные значения. В статье

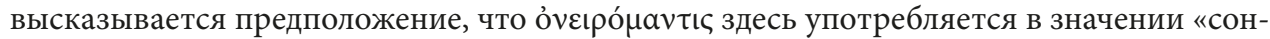
пророк», т.е. «пророческий сон».

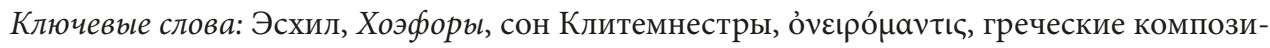
ты. 